\title{
Flocculation of a Methylomonas sp.: Possible Involvement of a Surface Protein
}

\author{
By GURI EGGSET, $†$ EVEN STENBERG $\ddagger$ AND JOHS. KJOSBAKKEN* \\ Department of Biochemistry, The Norwegian Institute of Technology, N-7034 Trondheim - NTH, \\ Norway
}

(Received 21 June 1983; revised 8 August 1983)

Chemostat-grown cells of a newly isolated strain of Methylomonas were flocculated by the addition of small amounts of positively charged flocculants. The flocculation ability of the cells was almost completely lost after extracting the cells with 1-5 mM-EDTA, or by reducing $\mathrm{pH}$ to below 4.5. Reconstitution of the flocculation ability of EDTA-extracted cells was obtained either by the addition of an excess amount of calcium ions, or by mixing dialysed EDTA extracts with EDTA-extracted cells. The EDTA extract contained mainly proteins. The major protein was purified to homogeneity by gel filtration, and had a molecular size of $65000 \mathrm{Dal}$ and an isoelectric point of $9 \cdot 0$. Immunological techniques indicated that this protein was located on the surface of the bacteria. We, therefore, propose that the surface protein of the Methylomonas sp. is involved in flocculation by positively charged flocculants.

\section{INTRODUCTION}

Flocculation as a means of separating bacteria from their growth medium is of considerable industrial importance. The efficiency of the activated sludge process for the treatment of effluent water depends to a large extent on bacteria which flocculate naturally during growth (Harris \& Mitchell, 1973; Pipes, 1978). Growth of bacteria for the industrial production of cell material (single cell protein), enzymes or metabolites depends on cheap methods of harvesting cells. This goal can be achieved very efficiently by inducing the cells to flocculate after growth in the fermenter (for reviews see Atkinson \& Daoud, 1976; Wang \& Sinskey, 1970).

In the past decade there has been considerable interest in utilizing bacteria grown on cheap carbon sources like methanol or methane for the production of protein-rich animal feed-stuff, and several processes have been proposed (Mogren, 1979; Senior \& Windass, 1980). A flocculation step for cell harvesting seems to be an integral part in these processes, and a number of such methods have been developed empirically. Little information concerning the detailed mechanisms underlying the various flocculation procedures is available.

In the present paper a Methylomonas sp. was flocculated with a positively charged, commercially available flocculant. We have studied this flocculation mechanism in some detail, and present evidence for the possible involvement of proteins located on the bacterial surface in the flocculation process.

\section{METHODS}

Bacterial strain and growth conditions. A methanol-oxidizing bacterium was isolated as described by Häggström (1975) and identified as a Methylomonas sp.

The strain was cultured continuously in a 4 litre fermenter (Chemoferm AB, Stockholm, Sweden) at a dilution rate of $0 \cdot 1 \mathrm{~h}^{-1}$. The medium with growth-limiting amounts of methanol (114 mM) was as described by Häggström

† Present address: Institute of Medical Biology, University of Tromsø, PO Box 977, N-9001 Tromsø, Norway.

$\ddagger$ Present address: Institute of Fishery Technology Research, PO Box 677, N-9001 Tromsø, Norway. 
(1975). Constant $\mathrm{pH}(6.6)$ was maintained by the addition of $1.4 \mathrm{M}-\mathrm{NH}_{4} \mathrm{OH}$. The growth temperature was $30^{\circ} \mathrm{C}$, the vessel stirring rate was 1000 r.p.m. and sterile air was supplied at a rate of $21 \mathrm{~min}^{-1}$. Cells were harvested by centrifugation $(6000 \mathrm{~g})$ at steady state conditions.

Flocculation experiments. The harvested cells were washed twice with $10 \mathrm{~mm}$-sodium phosphate buffer, $\mathrm{pH} \mathrm{6.6,}$ and resuspended in the same buffer to $1.6 \mathrm{~g}$ cells (dry wt) $1^{-1}$. This suspension is referred to as washed cell suspension. The washed cell suspension $(10 \mathrm{ml})$ was mixed with $10-100 \mu \mathrm{g}$ of the flocculant in water $\left(0.2 \mathrm{mg} \mathrm{ml}^{-1}\right)$, and stirred for $5 \mathrm{~min}$ at 100 r.p.m. The aggregates formed were sedimented by centrifugation for $5 \mathrm{~min}$ at $120 \mathrm{~g}$, and the turbidity of the supernatant was measured at $660 \mathrm{~nm}$. The percentage flocculation was calculated as follows:

$$
\text { Percentage flocculation }=100\left[1-\left(\mathrm{OD}_{\mathrm{R}} / \mathrm{OD}_{0}\right)\right]
$$

where $\mathrm{OD}_{\mathbf{R}}=$ turbidity of the supernatant after removal of flocculated cells, and $\mathrm{OD}_{0}=$ turbidity of the cell suspension before flocculation.

Treatment of bacterial cells. Extraction with EDTA was performed by mixing washed cell suspensions with a solution of EDTA in $10 \mathrm{~mm}$-phosphate buffer, $\mathrm{pH} 6.6$, to a final concentration of $1.6 \mathrm{~g}$ cells (dry wt) $1^{-1}$ and $1-$ $10 \mathrm{~mm}$-EDTA. The mixture was incubated with stirring for $1 \mathrm{~h}$ at $20^{\circ} \mathrm{C}$, and the cells were sedimented by centrifugation, washed twice and resuspended in phosphate buffer before flocculation as described above. The EDTAcontaining extract was used for further analysis.

For reconstitution of extracted protein on bacterial cell walls, cells extracted with $1 \mathrm{~mm}$-EDTA and washed were mixed with a $1 \mathrm{~mm}$-EDTA extract previously dialysed for $24 \mathrm{~h}$ at $4{ }^{\circ} \mathrm{C}$ against $1 \mathrm{~mm}-\mathrm{CaCl}_{2}$ in phosphate buffer. The mixture was incubated with gentle stirring for $20 \mathrm{~h}$ at $4{ }^{\circ} \mathrm{C}$. Alternatively, reconstitution was performed by the addition of $2 \cdot 5 \mathrm{~mm}-\mathrm{CaCl}_{2}$ to the cell suspension subsequent to extraction with 1 mM-EDTA and incubation for $1 \mathrm{~h}$.

Urea treatment of washed cell suspensions was carried out by stirring with $1 \mathrm{M}$-urea at $37^{\circ} \mathrm{C}$ for $2 \mathrm{~h}$. For papain treatment a concentration of $2 \mathrm{mg}$ enzyme $\mathrm{ml}^{-1}$ was used at $40^{\circ} \mathrm{C}$ for $1.5 \mathrm{~h}$. Cells were treated at low pH by adding $1 \mathrm{M}-\mathrm{HCl}$ and stirring for $1 \mathrm{~h}$ at $20^{\circ} \mathrm{C}$. In some experiments the $\mathrm{pH}$ was readjusted to 6.6 by the addition of $1 \mathrm{M}$ $\mathrm{NaOH}$ and the suspension was incubated further for $1 \mathrm{~h}$. The cells were always washed and resuspended in phosphate buffer prior to flocculation.

Gel filtration. Extracts from cells treated with 5 mM-EDTA were concentrated 50 -fold by ultrafiltration (Amicon, Diaflo filter PM 10), and fractionated on a column of Sepharose CL6B $(16 \times 700 \mathrm{~mm})$ with $50 \mathrm{~mm}$ phosphate buffer, pH 6.6. Combithek Calibration Protein II markers (Boehringer, Mannheim) were used as standards to estimate molecular sizes.

Electrophoresis. EDTA extracts, or fractions from the gel-filtration column were incubated with $1 \%$ (w/v) SDS and $1 \%(\mathrm{v} / \mathrm{v})$ mercaptoethanol for $2 \mathrm{~h}$. Disc electrophoresis was performed on $10 \%$ polyacrylamide gels in $0.1 \%$ (w/v) SDS as described by Weber \& Osborn (1969). The gels were stained with Coomassie brilliant blue R250 (BioRad). Low molecular weight protein standards (Bio-Rad) were used to estimate molecular sizes.

Electrofocusing. Crude EDTA extracts, or purified protein, were applied as $10 \mu 1$ drops on an Ampholine polyacrylamide gel plate (gel concentration $2 \cdot 4 \%$, supplied by LKB, Sweden) with a pH range of 3.5-9.5. Focusing was performed in the LKB Multiphor System at constant power $(25 \mathrm{~W})$. The pH gradient was determined with a surface electrode (LKB). The proteins were fixed with $3 \cdot 5 \%(\mathrm{w} / \mathrm{v})$ sulphosalisylic acid and $11 \cdot 5 \%(\mathrm{w} / \mathrm{v})$ trichloroacetic acid in water before staining with Coomassie brilliant blue R250 (1.15 $\mathrm{g}^{-1}$ destaining solution), and destaining against several changes of destaining solution $(25 \%(\mathrm{v} / \mathrm{v})$ ethanol and $8 \%(\mathrm{v} / \mathrm{v})$ acetic acid in water).

Production of antiserum. Purified protein $\left[1 \mathrm{mg}(\mathrm{ml} \text { saline })^{-1}\right]$ was intravenously injected weekly in a rabbit for 3 weeks. The rabbit was bled one week after the last injection. The blood was first incubated 4-5 h at room temperature and then overnight at $4{ }^{\circ} \mathrm{C}$ before the serum was pipetted off. This antiserum was used in the bacterial agglutination test, which was performed by mixing a suspension of bacteria $(20 \mu \mathrm{l})$ with an equal volume of diluted antiserum on glass plates. The highest dilution of antiserum which still gave visual agglutination was used as a semiquantitative index of agglutination.

Other methods. Protein assays were performed according to Bradford (1976) using the Bio-Rad dye assay reagent based on Coomassie brilliant blue G250. Polysaccharides were determined as glucose equivalents from the reaction with anthrone (Scott \& Melvin, 1953). RNA was analysed by the orcinol method (Ashwell, 1957).

Purified protein $\left(5 \mathrm{mg} \mathrm{ml}^{-1}\right)$ was hydrolysed in $6 \mathrm{M}-\mathrm{HCl}$ at $110^{\circ} \mathrm{C}$ for 24 and $68 \mathrm{~h}$. The hydrolysates were washed twice in distilled water before chromatography on an automatic amino acid analyser (Beckman, model 120C).

\section{RESULTS}

\section{Flocculation of bacterial cells}

Chemostat-grown cells were easily flocculated by the addition of several commercially available flocculants (Allied Colloids, Bradford, UK and Crosfield Polyelectrolytes, Warrington, 


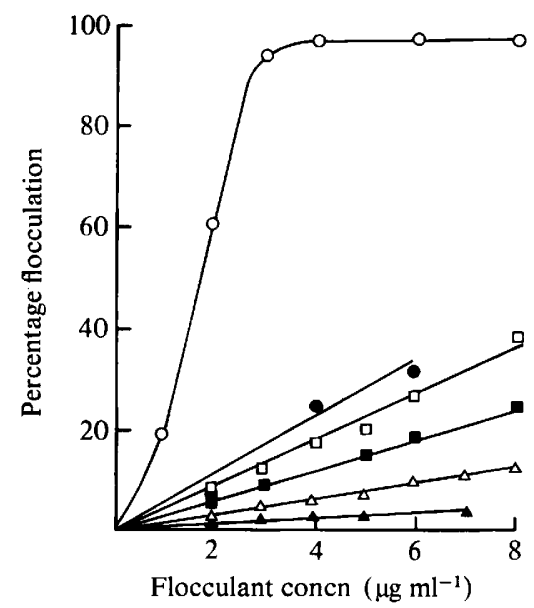

Fig. 1. Flocculation of untreated and extracted cells of a Methylomonas sp. with the flocculant Zetag 76. Chemostat-grown cells were extracted, resuspended in phosphate buffer and flocculated as described in Methods. $\mathrm{O}$, Untreated cells; $\boldsymbol{O}$, cells treated at $\mathrm{pH} 4 \cdot 5 ; \boldsymbol{\Delta}$, cells treated at $\mathrm{pH} 2 \cdot 0 ; \square$, cells extracted with $1 \mathrm{~mm}$-EDTA; $\square$, cells extracted with 5 mM-EDTA; $\triangle$, cells extracted with $10 \mathrm{~mm}$-EDTA.

U.K.). The flocculants were mostly positively charged, soluble polyacrylamide or polyamine based polymers. Details of their chemical structures were not available. One suitable flocculant, Zetag 76 (Allied Colloids), was chosen for further experiments. Complete flocculation was achieved at concentrations of $3 \mu \mathrm{g}(\mathrm{ml} \mathrm{Zetag} \mathrm{76)})^{-1}$ (Fig. 1). The flocculation of cells by Zetag 76 was used as a model system for further studies on the mechanism of flocculation.

\section{Treatment of cells with surface-modifying agents}

Regular patterns of protein layers on the surface of various bacteria have been described in several reports (for a review, see Sleytr, 1978). To study their possible involvement in the flocculation of our Methylomonas sp. several methods were used to disorganize or extract these layers.

Treatment of washed cell suspensions with urea or papain had only negligible effects on their flocculation. Cells which were incubated at $\mathrm{pH} 2.0$ or 4.5 , however, lost most of their flocculation ability (Fig. 1). No release of protein could be observed after this treatment. Flocculation was not restored by prior incubation at $\mathrm{pH} 6.6$.

Treatment of a washed cell suspension with 1,5 or 10 mM-EDTA drastically reduced the flocculation ability (Fig. 1). At low concentrations of Zetag 76 the effect of the three different EDTA concentrations was similar. Treatment with 1 mm-EDTA gave no apparent lysis of the cells, as judged by turbidity and RNA analysis, and this concentration was used for further flocculation experiments.

An appreciable amount of protein $\left(70 \mu \mathrm{g} \mathrm{ml}^{-1}\right)$ was released on treatment with $1 \mathrm{mM}$-EDTA, while the amount of RNA $\left(7 \mu \mathrm{g} \mathrm{ml}^{-1}\right)$ and carbohydrate $\left(8 \mu \mathrm{g} \mathrm{ml}^{-1}\right)$ liberated was low. The protein released accounted for $4.4 \%$ of the dry weight of the bacterium. SDS-electrophoresis of the EDTA extracts (Fig. $2 a$ ) revealed one dominant protein band corresponding to a molecular size of $65000 \mathrm{Dal}$ (denoted as the major protein), two minor bands with molecular sizes 45000 and $34000 \mathrm{Dal}$, and approximately ten very weak bands. Extraction of the cells with $5 \mathrm{~mm}$ EDTA instead of $1 \mathrm{mM}$-EDTA released more protein; up to $190 \mu \mathrm{g} \mathrm{ml}^{-1}$. The increase was mainly due to the liberation of more of the major protein (Fig. 2a).

\section{Isolation and characterization of the major protein}

The major protein was purified to homogeneity by gel filtration of a concentrated EDTA extract on Sepharose CL 6B. The major protein appeared as the dominating peak in the elution 
(a)
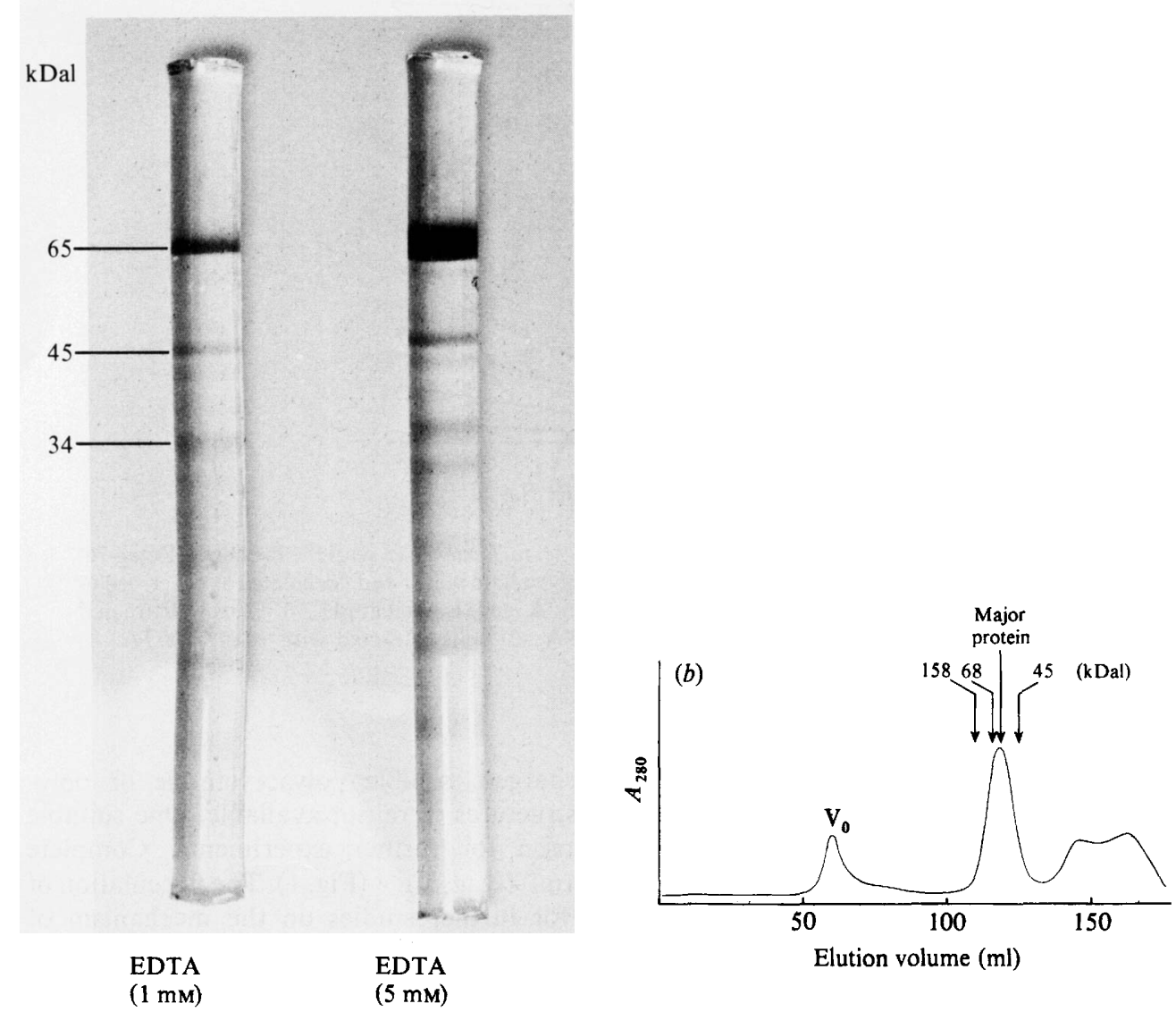

Fig. 2. Separation of proteins released by EDTA extraction of chemostat-grown cells of a Methylomonas sp. (a) SDS gel electrophoresis of $1 \mathrm{~mm}$ and $5 \mathrm{~mm}$-EDTA extracts. Samples were incubated in $1 \%$ SDS and $1 \%$ mercaptoethanol for $2 \mathrm{~h}$ prior to electrophoresis through $10 \%(\mathrm{w} / \mathrm{v})$ acrylamide gels containing $0.1 \%$ SDS. Standard proteins were run on separate gels (not shown). Molecular sizes of sample proteins are indicated. (b) Gel filtration of a $5 \mathrm{~mm}$-EDTA extract on Sepharose CL 6B. The molecular sizes of the major protein and standard proteins are indicated by arrows.

profile (Fig. $2 b$ ). A molecular size close to $65000 \mathrm{Dal}$ was estimated by running protein standards on the same column. This was in agreement with the molecular size determined by SDS-electrophoresis.

Isoelectric focusing of the protein in ampholine gel revealed an isoelectric point of $9 \cdot 0 \pm 0 \cdot 2$. This high value was confirmed by preliminary amino acid analysis (Table 1), which indicated an excess of basic amino acids. The major protein thus appeared to be a basic protein.

\section{Reconstitution of flocculation ability}

The flocculation ability which was lost by EDTA extraction could be restored by adding $\mathrm{CaCl}_{2}$ in excess. Cells treated with EDTA, but not washed, regained most of their flocculation ability on incubation with $\mathrm{CaCl}_{2}$ (Fig. 3).

Freshly extracted and washed cells regained $85 \%$ of the flocculation ability after incubation with an EDTA extract dialysed against $\mathrm{Ca}^{2+}$-containing buffer (Fig. 3). We were not able to restore the flocculation ability of EDTA-extracted cells by the addition of the purified major protein, at concentrations of up to approximately $50 \mathrm{mg}$ (g dry wt cells) ${ }^{-1}$. 


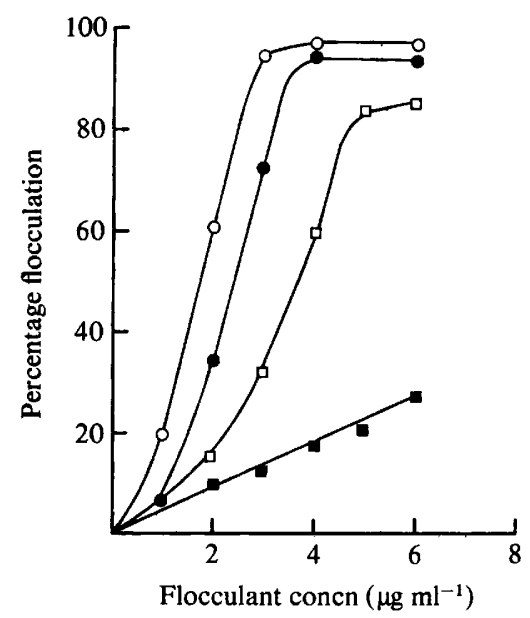

Fig. 3. Partial reconstitution of the flocculation ability of a Methylomonas sp. lost by EDTA extraction. The experiments were performed with the flocculant Zetag 76. $O$. Untreated cells; $O$, cells incubated in the presence of $2.5 \mathrm{~mm}-\mathrm{Ca}^{2+}$ after treatment with $1 \mathrm{mM}$-EDTA; $\square$, cells extracted with $1 \mathrm{mM}-\mathrm{EDTA}$ and incubated with a dialysed EDTA extract before flocculation; $\square$, cells extracted with 1 mM-EDTA.

Table 1. Amino acid composition of the major protein from the Methylomonas sp.

$\begin{array}{lclc}\text { Amino acid } & \begin{array}{c}\text { Content } \\ (\mathbf{m o l} \%)\end{array} & \text { Amino acid } & \begin{array}{c}\text { Content } \\ (\mathbf{m o l} \%)\end{array} \\ \text { Lysine } & 9.9 & \text { Glycine } & 10.1 \\ \text { Histidine } & 2 \cdot 1 & \text { Alanine } & 8.6 \\ \text { Arginine } & 3.0 & \text { Valine } & 6.5 \\ \text { Aspartic acid } & 12.7 & \text { Methionine } & 2.3 \\ \text { Threonine } & 6.3 & \text { Isoleucine } & 3.8 \\ \text { Serine } & 4.7 & \text { Leucine } & 6.9 \\ \text { Glutamic acid } & 9.3 & \text { Tyrosine } & 3.6 \\ \text { Proline } & 6.8 & \text { Phenylalanine } & 3.3\end{array}$

\section{Bacterial agglutination test}

Antiserum raised against the purified major protein easily agglutinated a suspension of washed bacterial cells up to a serum dilution of $1: 128$ (when mixed $1: 1$ ). This strongly indicated that the major protein was located on the bacterial cell surface. Bacteria extracted with $1 \mathrm{mM}-$ EDTA and washed were agglutinated only up to $1: 32$ serum dilution indicating that far less protein was available for agglutination. Serum obtained from non-immunized rabbits gave no detectable agglutination.

\section{DISCUSSION}

To study the mechanism of flocculation, we have consistently used washed bacteria to avoid interference by the growth medium or extracellular polysaccharides produced by Methylomonas (Häggström, 1975). Most bacteria have negatively charged surfaces at neutral pH (Harden \& Harris, 1953). Our Methylomonas sp. was readily flocculated with positively charged polymers indicating the presence of negative charges on the surface of this strain.

The treatment of the strain with 1 mM-EDTA liberated protein and small amounts of carbohydrate and RNA. According to Leive \& Morrison (1972), the carbohydrate might be part of the lipopolysaccharide. The amount of RNA released was low, indicating negligible lysis of the cells. Lysis could not be observed microscopically. Only $4 \%$ of the EDTA-treated cells, 
however, could form colonies on agar medium. It has been postulated that major outermembrane proteins may be essential for Gram-positive (Howard \& Tipper, 1973) and for some Gram-negative bacteria (Osborn \& Wu, 1980).

The major protein with a molecular size of about $65000 \mathrm{Dal}$ represented more than $50 \%$ of the total proteins extracted with EDTA from chemostat-grown Methylomonas sp. It is possible that this protein covers the cell surface, possibly in a regular pattern. Such layers have been described for many different bacteria including a Methylomonas sp. (Wilkinson, 1971). Our results have indicated that such a possible protein layer may be attached to the cell surface by means of divalent cations. $\mathrm{Ca}^{2+}$ or $\mathrm{Mg}^{2+}$ was reported to be required for the attachment of the major protein on the surface of an Acinetobacter strain (Thorne, 1977). Furthermore, it has been found that Spirillum serpens contains surface protein only in the presence of $\mathrm{Ca}^{2+}$ (Buckmire \& Murray, 1970).

As the major protein of our Methylomonas sp. might cover the cell surface, it could be responsible for cell flocculation on addition of positively charged flocculants. The flocculation ability was lost almost completely when this protein was removed by EDTA extraction. We were able to restore much of the flocculation ability by opposing the effect of EDTA (adding excess $\mathrm{Ca}^{2+}$ or removing EDTA). This may lead to reconstitution of protein on the cell surface. We were not able to restore flocculation ability by mixing the purified major protein with cells extracted with EDTA in the presence of $\mathrm{Ca}^{2+}$. This could be due to removal during the purification process of carbohydrate components (Masuda \& Kawata, 1981), LPS (Osborn \& $\mathrm{Wu}, 1980$ ), or other components essential for the reconstitution. However, the flocculation could be more complex than we have suggested, depending on several surface proteins and other components liberated by EDTA.

Low $\mathrm{pH}$ has been reported to denature bacterial cell surface proteins (Sleytr \& Thorne, 1976). In our case, $\mathrm{pH}$ lower than 4.5 irreversibly abolished the flocculation ability of the cells, possibly by denaturing surface protein. Negligible amounts of protein were released on treatment at low $\mathrm{pH}$.

Cells grown in batch culture without $\mathrm{pH}$ control could be flocculated when harvested from the exponential phase, but not after entering the stationary phase where $\mathrm{pH}$ would have dropped to below 5.0. EDTA extraction of cells from exponential phase gave mainly the major protein, while extraction of stationary-phase cells released only small amounts of this protein and several other proteins dominated (data not shown).

The major protein $(65000 \mathrm{Dal})$ appears to consist of one single polypeptide chain with isoelectric point close to 9 and with more basic than acidic amino acids. At $\mathrm{pH} 6.6$ there would be a total surplus of positive charges on this protein. To bind a positively charged flocculant we must postulate that there are negative regions available on the bacterial surface, and the major protein might have a configuration in situ which makes this possible. Major outer-membrane proteins isolated from other bacteria seem to be more acidic than the protein which we have isolated from a Methylomonas sp. Bacillus sphaericus has a major surface protein with $10-15 \%$ excess of acidic amino acids (Howard \& Tipper, 1973). Surface proteins from Vibrio cholerae and a strain of Acinetobacter were also acidic (Kabir, 1980; Thornley et al., 1974).

Endo et al. (1976) and Endo \& Takahashi (1980) have shown that the flocculation of a naturally flocculating strain of Flavobacterium was lost after EDTA or pronase treatment. Flocculation could be partially restored by the addition of calcium ions, indicating that surface proteins were involved in flocculation.

This work was supported by a grant from the Royal Norwegian Council for Scientific and Industrial Research. We acknowledge the able technical assistance of Mrs Anne-Lise Ustad.

\section{REFERENCES}

ASHWELL, G. (1957). Colorimetric analysis of sugars. Methods in Enzymology 3, 73-105.

AtKinson, B. \& DaOud, I. S. (1976). Microbial flocs and flocculation in fermentation process engineering. Advances in Biochemical Engineering 4, 41-124.
BRADFORD, M. M. (1976). A rapid and sensitive method for the quantitation of microgram quantities of protein utilizing the principle of protein-dye binding. Analytical Biochemistry 72, 248-254. 
Buckmire, F. L. A. \& Murray, R. G. E. (1970). Studies on the cell wall of Spirillum serpens. 1. Isolation and partial purification of the outermost cell wall layer. Canadian Journal of Microbiology 16, 1011-1022.

ENDO, T. \& TAKAHASHI, H. (1980). Reconstitution of pronase susceptible flocs of Flavobacterium sp. Agricultural and Biological Chemistry 44, 2413-2418.

Endo, T., Nakamura, K. \& Takahashi, H. (1976). Pronase-susceptible floc forming bacteria: relationship between flocculation and calcium ions. Agricultural and Biological Chemistry 40, 2289-2295.

HÄGGSTRÖM, L. (1975). Methanol utilizing bacteria for single cell protein production. $\mathrm{Ph}$.D. thesis, University of Lund, Sweden.

HARDEN, V. P. \& HaRRIS, J. O. (1953). The isoelectric point of bacterial cells. Journal of Bacteriology 65, 198-202.

HaRris, R. H. \& Mitchell, R. (1973). The role of polymers in microbial aggregation. Annual Review of Microbiology 27, 27-50.

Howard, L. \& Tipper, D. J. (1973). A polypeptide bacteriophage receptor: modified cell wall protein subunits in bacteriophage-resistant mutants of Bacillus sphaericus strain P-1. Journal of Bacteriology 113, 1491-1504.

KABIR, S. (1980). Composition and immunochemical properties of outer membrane proteins of Vibrio cholerae. Journal of Bacteriology 144, 382-389.

LEIVE, L. \& MORRISON, D. C. (1972). Isolation of lipopolysaccharides from bacteria. Methods in Enzymology 28, 254-262.

MASUDA, K. \& KaWATA, T. (1981). Characterization of a regular array in the wall of Lactobacillus buchneri and its reattachment to the other wall components. Journal of General Microbiology 124, 81-90.

Mogren, H. (1979). SCP from methanol - the Norprotein process. Process Biochemistry 143, 2-7.
Osborn, M. J. \& Wu, H. C. P. (1980). Proteins of the outer membrane of Gram-negative bacteria. Annual Review of Microbiology 34, 369-422.

PIPES, W. O. (1978). Microbiology of activated sludge bulking. Advances in Applied Microbiology 24, 85127.

SCOTT, T. A. \& MELVIN, E. H. (1953). Determination of dextran with anthrone. Analytical Chemistry 25, 1656-1661.

SENIOR, P. J. \& Windass, J. (1980). The ICI single cell protein process. Biotechnology Letters 2, 205-210.

SLEYTR, U. B. (1978). Regular arrays of macromolecules on bacterial cell walls: structure, chemistry, assembly and function. International Review of Cytology 53, 1-64.

Sleytr, U. B. \& Thorne, K. J. I. (1976). Chemical characterization of the regularly arranged surface layers of Clostridium thermosaccharolyticum and Clostridium thermohydrosulfuricum. Journal of Bacteriology 126, 377-383.

THORNE, K. J. I. (1977). Regularly arranged protein on the surfaces of Gram-negative bacteria. Biological Reviews 52, 219-234.

Thornley, M. J., Glauert, A. M. \& Sleytr, U. B. (1974). Structure and assembly of bacterial surface layers composed of regular arrays of subunits. Philosophical Transactions of the Royal Society. Series B 268, 147-153.

WANG, D. I. C. \& Sinskey, A. J. (1970). Collection of microbial cells. Advances in Applied Microbiology 12, 121-152.

WEBER, K. \& OsBorn, M. (1969). The reliability of molecular weight determinations by dodecyl sulfatepolyacrylamide gel electrophoresis. Journal of Biological Chemistry 244, 4406-4412.

WILKINSON, J. F. (1971). Hydrocarbons as a source of single-cell protein. Symposia of the Society for General Microbiology 21, 15-46. 